\title{
Processing of Mozzarella cheese wheys and stretchwaters: A preliminary review
}

\author{
Gwénolé Gernigon, Pierre Schuck*, Romain Jeantet \\ INRA, UMR 1253, F-35000 Rennes, France \\ AGROCAMPUS OUEST, UMR1253, F-35000 Rennes, France
}

\begin{abstract}
Received 10 March 2009 - Revised 24 September 2009 - Accepted 1st October 2009
Published online 10 November 2009
\end{abstract}

\begin{abstract}
Mozzarella cheese is one of the cheeses that has achieved the most significant growth in production in the past century. This has resulted in the concomitant production of large amounts of whey and (in the case of Mozzarella cheese) stretchwater. For decades, these products were often dumped as waste products or used as animal feed. However, it is no longer possible to do so. First, these by-products have a high oxygen demand, and thus a great environmental impact. Second, the high nutritional value of their constituents (whey protein, lactose, etc.) makes it necessary to make use of these products and, as food ingredients, this begins with concentration and spray drying of the bulk material. These stages are known to be especially difficult in the case of Mozzarella cheese wheys and stretchwaters, and there is thus a need to study and explain the role of the minor compounds that were found in Mozzarella cheese wheys, including water-binding properties and low glass transition temperature. Solving these problems requires a good understanding of the origins of these by-products (i.e. Mozzarella cheese making) and of water dynamics. The aim of this review is to provide an overview of the current knowledge on the composition of Mozzarella cheese wheys and stretchwaters, their origin in cheese making and the possible implications of their composition on the different water elimination stages.
\end{abstract}

\section{Mozzarella cheese / whey / spray drying / water dynamics / pasta filata}

\begin{abstract}
摘要 - Mozzarella 干酪乳清和拉伸水的处理一一综述。近一个世纪以来, Mozzarella 干 酪 的产量得以快速增长, 结果是伴随着大量乳清和拉伸水的排放。几十年来, 排出的乳清和 拉伸水作都是以废水排放或者作为动物饲料。然而, 这种做法不再允许了。首先, 这些副 产物的需氧量较高, 对环境的压力较大; 其次, 乳清成分的营养价值较高(乳清蛋白、乳糖 等)，有必要浓缩和干燥这些组分用作食品的配料。但是这些处理过程对 Mozzarella 干酪 乳清和拉伸水来讲是非常困难的, 因此有必要进一步深入研究和探讨乳清和拉伸水中微量化 合物的作用、束缚水的特性以及低玻璃相转化温度。解决这些问题需要掌握这些副产物的 来源 (如 Mozzarella 干酪的制造) 和水动力学。本文概述了 Mozzarella 干酪乳清和拉伸 水的组成、干酪制造过程、以及不同阶段排出废水中可能的成分。
\end{abstract}

\section{Mozzarella 干酪 / 乳清 / 喷雾干燥 / 水动力学 / pasta filata}

Résumé - Traitement des lactosérums et des eaux de filage de Mozzarelle - revue préliminaire. La Mozzarella est l'un des fromages dont la production a connu la plus forte progression ces cinquante dernières années. Une telle évolution s'accompagne inévitablement d'une production croissante de coproduits, le lactosérum et l'eau de filage. Pendant des décennies, ces coproduits

*Corresponding author (通讯作者): pierre.schuck@rennes.inra.fr 
n'étaient pas valorisés, ce qui n'est plus envisageable aujourd'hui. D'une part, pour des raisons environnementales, étant donné que ces produits ont une très forte demande en oxygène, et donc un fort pouvoir polluant. D'autre part, pour des raisons économiques, étant donné la valeur nutritionnelle de leurs constituants (protéines sériques, lactose...), il est intéressant de les valoriser en tant qu'ingrédients alimentaires après concentration et séchage par atomisation. Dans le cas des coproduits issus de la fabrication de Mozzarella, cette étape est problématique, du fait de la présence de composés hygroscopiques, et aboutit souvent à d'importants problèmes de faibles niveaux de concentration, de mauvaise cristallisation du lactose et enfin de collage en tour et mottage des poudres obtenues. La résolution de ces problèmes nécessite une bonne connaissance de l'origine de ces coproduits, c'est-à-dire du procédé de fabrication de la Mozzarella, et de la dynamique de l'eau au cours des opérations de concentration et de séchage. Cette revue a pour but de synthétiser les connaissances sur la composition des lactosérums de Mozzarella, leur origine, c'est-à-dire le procédé fromager, et l'influence possible de leur composition sur les différentes étapes d'élimination d'eau.

\section{Mozzarelle / lactosérum / séchage / dynamique de l'eau / pâte filée}

\section{INTRODUCTION}

Due to the success of the pizza, there has been a spectacular growth in the production of one of its major ingredients, Mozzarella cheese, since the middle of the 20th century. Production volumes for a given factory have been reported to reach up to 100 tons of cheese per day [29] and the annual growth in production of this cheese has reached $10 \%$ in North America [33] and $7 \%$ in the UK [35]. The annual amount of Mozzarella produced in France went from 4655 tons in 1996 to 23636 tons in 2005 [8], which is a fivefold growth in production in 10 years. Such production unavoidably results in large amounts of by-products: indeed, whey production is equal to ninefold the cheese tonnage produced [50], and the stretching step specific to pastafilata cheeses results in the concomitant production of an effluent called stretchwater.

In the past, whey was considered to be an onerous by-product and was spread on the fields or used as cattle feed. Nowadays, due to the stringent environmental regulations that forbid the dumping of high oxygen-demanding products such as whey, and the scientific demonstration of the nutritional qualities of whey components (whey proteins, lactose, etc.) and the fractionation techniques developed mainly since the 1970s (especially membrane techniques), whey is better used as an ingredient or an ingredient precursor (see reviews of Webb and Whittier [55], Kosikowski [31] and Smithers [52] for an overview of the evolution of whey utilization).

Whey processing often involves concentration and spray drying, non-hygroscopic whey powder production being a convenient means to stabilize the product biologically by decreasing the $a_{\mathrm{w}}$. However, whey remains a product that is sometimes difficult to dry, as its composition includes water retaining compounds such as lactose, leading in many cases to stickiness during spray drying or caking during storage of the powders. As these problems often originate from the very hygroscopic amorphous lactose appearing during spray drying of crude whey, the drying stage is always preceded by a pre-crystallization stage, so that most of the lactose is crystallized before the spray-drying stage. In the case of Mozzarella cheese whey and stretchwater, this stage and the preceding concentration stage are often problematic, resulting in insufficient dry matter and degree of crystallization and sticking during the subsequent spray-drying stage (personal communication and industrial data). The reactions involved in these processing stages are therefore probably hindered by various other as yet undefined components, and/or their possible interactions with water or other compounds, resulting in industrial issues. 
Solving these problems is thus a significant challenge, both at the industrial level and from a scientific point of view. It requires awareness of the manufacturing processes, characterization of whey composition and understanding of water dynamics and its relationship with the different compounds that are present in Mozzarella cheese wheys.

The purpose of this review, which is a preliminary to the study of the composition of Mozzarella cheese wheys, is therefore to show the state of current information concerning the composition of Mozzarella cheese wheys, their origin (i.e. Mozzarella cheese making) and the possible implications of their composition on water elimination stages.

\section{DIFFERENT INDUSTRIAL PROCESSES IN THE MANUFACTURE OF MOZZARELLA CHEESE}

The rapid improvement in the science and technology of Mozzarella cheese making during the 20th century [28], as well as emerging new demands from the associated industries and consumers, means that a range of processes have to be described because they can lead to different cheese and whey compositions.

\subsection{The low moisture part skim Mozzarella cheese manufacturing process}

The low moisture part skim (LMPS) Mozzarella cheese, also called pizza cheese, is the main type of Mozzarella cheese that is manufactured industrially, due to its lower water content compared to traditional Mozzarella, which lengthens its shelf-life [27]. It is manufactured according to a process similar to that of cheddar until the stretching step that is specific to pasta-filata cheeses, and which defines the unique functional properties of this kind of cheese (Fig. 1).
The treatment of Mozzarella cheese milk begins with a high level of pasteurization, aimed at destroying pathogens as well as denaturing part of the whey proteins in order to improve cheese yield. Pasteurization is followed by a standardization of the milk in terms of caseins to milk fat ratio to achieve a satisfactory fat to dry matter ratio in the cheese.

The starter culture is then added. The main purpose of adding a starter culture is to achieve sufficient acidification of the milk by the microorganisms in order to reach optimal $\mathrm{pH}$ and calcium content for the stretching step. The starter cultures used for Mozzarella cheese making are commonly thermophilic bacteria such as Streptococcus thermophilus and Lactobacillus bulgaricus or sometimes Lactobacillus helveticus, the latter being used mainly for its specific ability to ferment galactose. In fact, most strains of $S$. thermophilus and L. bulgaricus do not have this ability.

Indeed, galactose accumulation in the cheese leads to excessive browning of the cheese during baking of the pizza due to the Maillard reaction [3].

The subsequent stages are renneting, coagulum cutting, cooking and whey draining. During these stages, the curd reaches its final characteristics in terms of moisture (depending on the temperature and cooking time) and calcium content.

The curd is then milled and cheddared, and at the end of the cheddaring step a $\mathrm{pH}$ window of $\sim 0.3 \mathrm{pH}$ units is achieved, during which the curd can be stretched. Depending on the time at which the stretching is carried out, different types of cheese will be obtained.

Mozzarella cheese arrives at its definitive functional properties only after the stretching stage, this stage consisting of immersion in hot water $\left(55-85^{\circ} \mathrm{C}\right)$ followed by a range of mechanical stresses through a screw. Combining heat treatment and strong shear constraints leads to a spatial rearrangement 


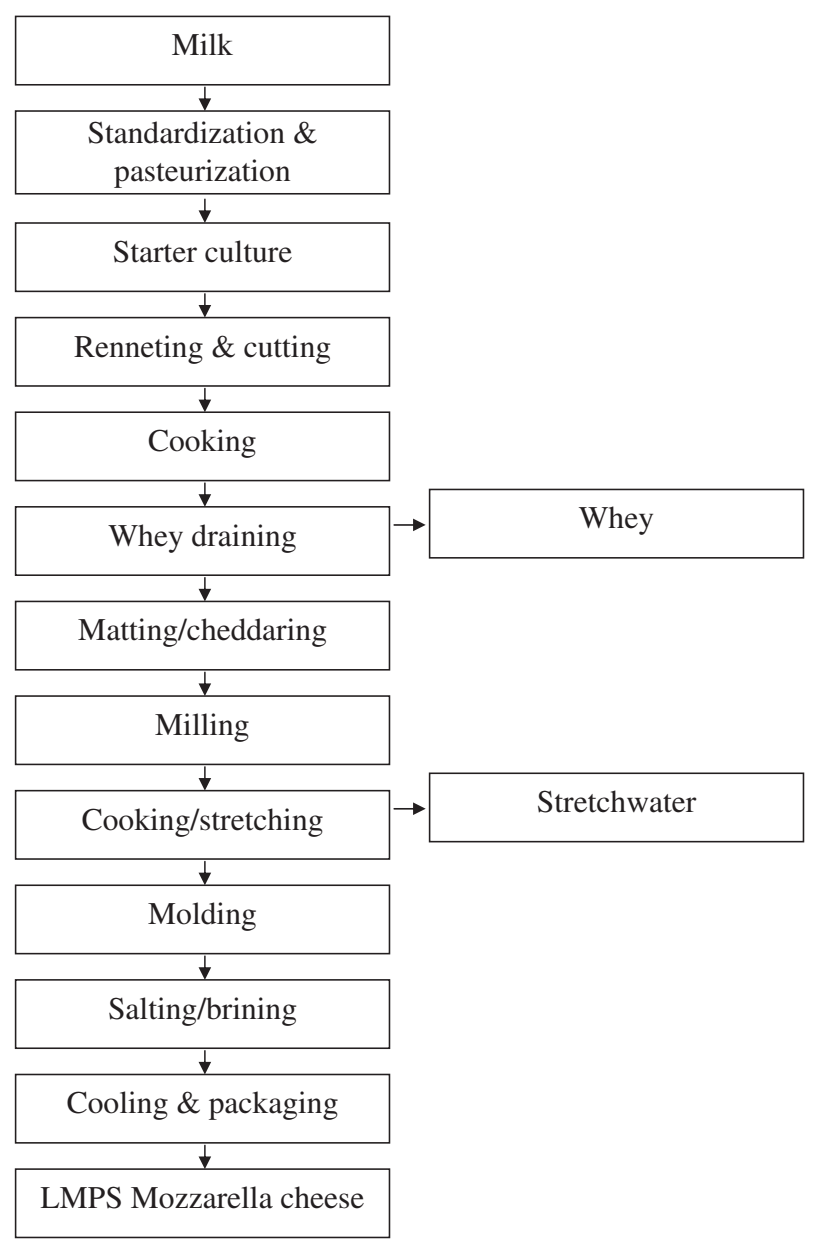

Figure 1. Manufacture diagram of LMPS Mozzarella cheese. (Adapted from [9].)

of the protein matrix in a lattice of parallel fibres between which the fat and whey droplets lie. Managing this stage requires good balance between the temperature of the curd and the screw speed [29].

The curd is then extruded into a mould in which it is pre-cooled before being salted in brine. Salting of Mozzarella cheese is carried out using cool brine $\left(1-4^{\circ} \mathrm{C}\right)$. Mozzarella cheese can also be dry salted or pre-salted just after cooking, in this case a diluted brine should be used as stretchwater, in order to avoid salt loss during stretching. The main advantage of dry salting is avoiding risks of contamination by yeast or mould that can occur when using brine [2]. It also makes it possible to obtain a homogeneously salted product, with positive consequences for the functional properties. Depending on the time it is carried out, pre-salting can yield a salty whey that has substantially increased amounts of lactoferrin, as described by Blaschek et al. [4]. 


\subsection{Variants of the Mozzarella cheese manufacturing process}

\subsubsection{Direct acidification process}

Developed by Breene et al. [5], this process differs from the above in that it uses no starter culture. Milk is in fact directly acidified before renneting by organic acids (citric, acetic or lactic acid) or by adding glucono- $\delta$-lactone [15] until a $\mathrm{pH}$ close to 5.6 is reached, which is constant during the whole process. The stretching $\mathrm{pH}$ is higher than that for cultured Mozzarella cheese (pH 5.3). In spite of certain different characteristics (e.g. more free fat), the cheese resulting from this process is similar to conventional Mozzarella cheese in terms of functionality. Keller et al. [26] showed that the choice of the acid affects the demineralization of the curd. Cheeses produced by direct acidification with citric or malic acid showed calcium losses in the whey $(>80 \%)$, whereas cheeses directly acidified by phosphoric acid lost only $50 \%$. This technological parameter thus influences both the functional properties of the cheese and the whey composition.

This process has grown in interest since the $1990 \mathrm{~s}$, because of the easier control of the acidification step and the suppression of ageing, in contrast to conventional Mozzarella cheese that requires ripening for 2-3 weeks before reaching the required functional qualities [28]. Finally, the direct acidification process is of interest for producing reduced-fat Mozzarella cheese because of the increased water retention [32]. However, it must be remembered that direct acidification can modify the types of acid present in the whey [26].

\subsubsection{Reduced-fat Mozzarella cheese}

To meet the increasing demand for lowfat products, reduced-fat Mozzarella cheese production results in a cheese with reduced functional properties. In fact, the protein lattice is denser and less hydrated, the low water retention becoming worse during baking of the pizza due to the low level of free fat at the surface, resulting in water evaporation and lower spreadability of the cheese.

In order to increase the water retention in reduced-fat Mozzarella cheese, Perry et al. [41] have demonstrated the possibility of using exopolysaccharide (EPS)-producing strains of $S$. thermophilus. However, Petersen et al. [42] have shown that the use of ropy EPS-producing strains could lead to an increase in the whey viscosity. Therefore, only capsular EPS-producing strains should be used.

The density of the protein lattice can be decreased by reducing the amount of calcium available for bridging the several casein aggregates by pre-acidifying the milk before adding the starter culture or by manufacturing the cheese by direct acidification. However, the loss of proteins resulting from this technology may result in a decreased cheese yield [36].

\subsubsection{Manufacturing Mozzarella cheese from retentates}

Following the publication of the MMV patent [34], several attempts were made to produce Mozzarella cheese from ultrafiltration retentates. Poor results were obtained in terms of the ability of the cheese to stretch [30], due, in particular, to too high a concentration of insoluble minerals. However, Fernandez and Kosikowski [12] obtained Mozzarella cheese with satisfactory functional properties from ultrafiltration retentates with a volume concentration ratio of $<2$.

A process for manufacturing Mozzarella cheese from $0.1 \mu \mathrm{m}$ microfiltration retentates has recently been developed by ArdissonKorat and Rizvi [1]. (Fig. 2). Mozzarella cheese produced by this process has a similar composition to conventionally produced Mozzarella cheese, but has a longer ripening time. One advantage of this process is 


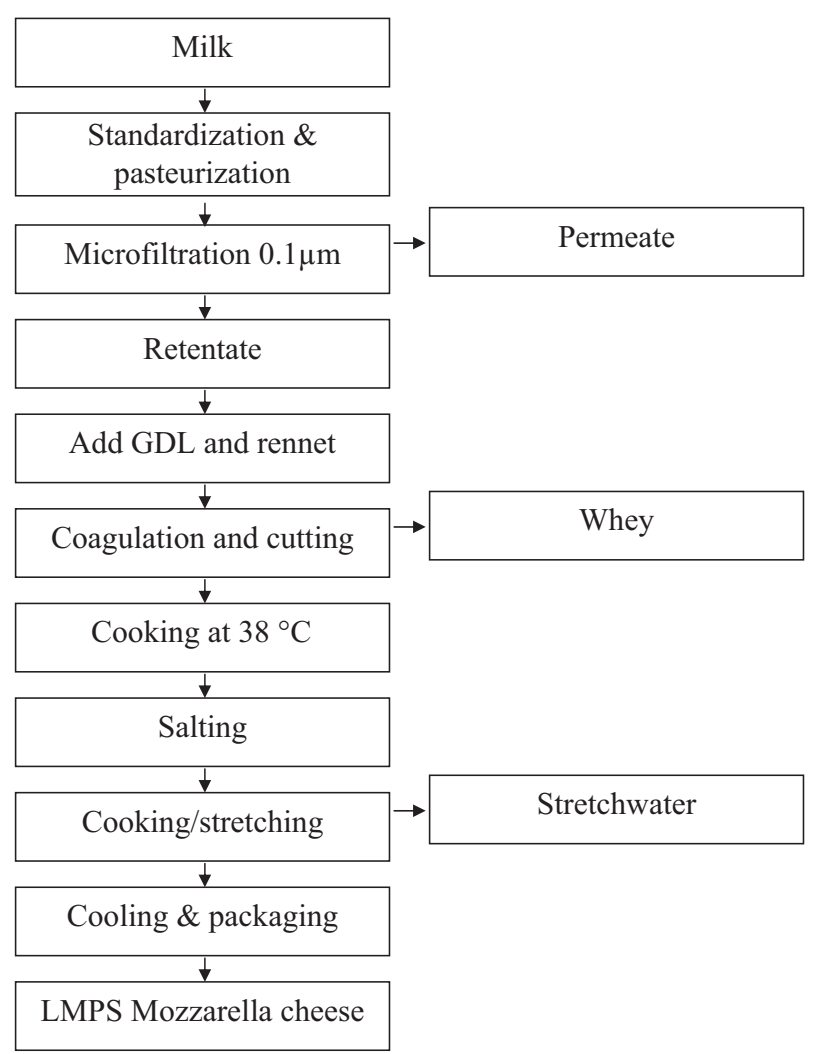

Figure 2. Continuous manufacture of LMPS Mozzarella cheese from microfiltration retentates. (Adapted from [1].)

in being able to obtain a milk permeate similar to virgin whey, and thus easier to process than whey. However, the residual whey is very concentrated.

\subsection{Recent developments in Mozzarella cheese technology}

As Mozzarella cheese production is constantly increasing, more and more research is being undertaken to improve process efficiency and product quality and functionality.

Chen et al. [7] conceived a process for making pasta filata-simulative cheeses without stretching. In this process, mesophilic rather than thermophilic starters are used, and the stretching stage is replaced by hooping and pressing the curd. The resulting cheese has a rheological behaviour that is similar to that of conventional Mozzarella; it is whiter and does not brown during baking due to the use of mesophilic starters. Moreover, it does not require any mixermoulder, which can be advantageous for cheese makers wishing to convert their production to pizza cheese without making extensive investments.

Ferrari et al. [13] developed a more efficient process in which the spinning and forming stages are performed simultaneously in a newly conceived extruding device. The advantages of this new system 
Table I. Gross composition of Mozzarella cheese wheys and stretchwaters as found in the literature.

\begin{tabular}{|c|c|c|c|c|c|c|c|c|}
\hline References & Type of sample & $\begin{array}{c}\text { Dry matter } \\
(\% \mathrm{w} / \mathrm{w})\end{array}$ & $\begin{array}{c}\text { Fat } \\
(\% \mathrm{w} / \mathrm{w})\end{array}$ & $\begin{array}{c}\mathrm{TN} \\
(\% \mathrm{w} / \mathrm{w})\end{array}$ & $\begin{array}{l}\text { Proteins } \\
(\% \mathrm{w} / \mathrm{w})\end{array}$ & $\begin{array}{l}\text { Lactose } \\
(\% \mathrm{w} / \mathrm{w})\end{array}$ & $\begin{array}{c}\text { Ash } \\
(\% \mathrm{w} / \mathrm{w})\end{array}$ & $\mathrm{pH}$ \\
\hline Rektor and Vatai [44] & Normal whey & 5.87 & 0.79 & & 0.72 & 3.90 & 0.46 & \\
\hline \multirow[t]{2}{*}{ Blaschek et al. [4] } & Sweet whey & 8.50 & 0.40 & & 1.00 & & & \\
\hline & Salty whey & 8.60 & 0.60 & & 0.70 & & & \\
\hline \multirow[t]{2}{*}{ Metzger et al. [36] } & Normal whey & $6.56-6.91$ & $0.06-0.11$ & $0.89-0.96$ & & & & \\
\hline & Stretchwater & & $0.04-0.07$ & $0.06-0.12$ & & & & \\
\hline \multirow[t]{2}{*}{ Rudan et al. [46] } & Normal whey & $6.59-7.02$ & $0.07-0.53$ & $0.88-0.91$ & & & & \\
\hline & Stretchwater & & $0.06-1.18$ & $0.07-0.11$ & & & & \\
\hline \multirow[t]{2}{*}{ Schafer and Olson [47] } & Normal whey & $6.47-6.65$ & $0.06-0.17$ & & & & & \\
\hline & Stretchwater & $0.28-0.56$ & $0.03-0.23$ & & & & & \\
\hline Fernandez and Kosikowski [12] & Normal whey & $6.30-8.00$ & $0.14-0.62$ & $0.87-1.60$ & & $4.85-5.70$ & & \\
\hline \multirow[t]{2}{*}{ Ardisson-Korat and Rizvi [1] } & Normal whey & $10.95-11.5$ & $1.42-1.80$ & $1.82-2.13$ & $1.43-1.68$ & & & \\
\hline & Stretchwater & $5.57-6.66$ & $0.20-0.65$ & $0.08-0.27$ & $0.01-0.20$ & & & \\
\hline Doultani et al. [11] & Normal whey & & & 0.85 & & & & 6.40 \\
\hline Guinee et al. [16] & Normal whey & & $0.34-0.38$ & $1.09-1.12$ & & & & \\
\hline Punidadas et al. [43] & Normal whey & & $0.40-0.51$ & $0.81-0.85$ & & & & \\
\hline Walsh et al. [54] & Normal whey & & $0.35-0.59$ & $1.03-1.06$ & & & & \\
\hline \multirow[t]{2}{*}{ Hill et al. [20] } & Normal whey & 5.8 & & 0.75 & & & & 6.63 \\
\hline & Concentrated whey & $12.3-25$ & & $1.57-2.87$ & & & & $6.26-6.54$ \\
\hline Teixeira and Fonseca [53] & Normal whey & 6.33 & 0.77 & 0.84 & & 4.42 & 0.47 & 6.19 \\
\hline
\end{tabular}

Abbreviation: TN, total nitrogen. 
Table II. Breakdown of protein composition of Mozzarella cheese wheys and stretchwaters as found in the literature.

\begin{tabular}{|c|c|c|c|c|c|c|c|}
\hline References & Type of sample & Proteins $(\% \mathrm{w} / \mathrm{w})$ & ALA (\% WP) & BLG (\% WP) & $\operatorname{IgG}(\% \mathrm{WP})$ & BSA (\% WP) & LF (\% WP) \\
\hline Rektor and Vatai [44] & Normal whey & 0.72 & & & & & \\
\hline \multirow[t]{2}{*}{ Blaschek et al. [4] } & Sweet whey & 1.00 & 25.4 & 59.3 & 3.8 & 2.2 & 1.9 \\
\hline & Salty whey & 0.70 & 21.9 & 53.0 & 4.3 & 2.2 & 8.9 \\
\hline \multirow[t]{2}{*}{ Ardisson-Korat and Rizvi [1] } & Normal whey & $1.43-1.68$ & & & & & \\
\hline & Stretchwater & $0.01-0.20$ & & & & & \\
\hline Doultani et al. [11] & Normal whey & & 22.17 & 64.52 & 0.06 & 0.06 & 0.01 \\
\hline
\end{tabular}

Abbreviations: ALA, $\alpha$-lactalbumin; BLG, $\beta$-lactoglobulin; IgG, immunoglobulin- $\gamma$; BSA, bovine serum albumin; LF, lactoferrin; WP, whey proteins. 
Table III. Breakdown of the mineral composition of Mozzarella cheese wheys and stretchwater as found in the literature.

\begin{tabular}{|c|c|c|c|c|c|c|c|c|}
\hline References & Type of sample & $\begin{array}{c}\text { Ash } \\
(\% \mathrm{w} / \mathrm{w})\end{array}$ & $\begin{array}{c}\mathrm{Na}^{+} \\
(\% \mathrm{w} / \mathrm{w})\end{array}$ & $\begin{array}{c}\mathrm{K}^{+} \\
(\% \mathrm{w} / \mathrm{w})\end{array}$ & $\begin{array}{c}\mathrm{Ca}^{2+} \\
(\% \mathrm{w} / \mathrm{w})\end{array}$ & $\begin{array}{c}\mathrm{Mg}^{2+} \\
(\% \mathrm{w} / \mathrm{w})\end{array}$ & $\begin{array}{c}\mathrm{Cl}^{-} \\
(\% \mathrm{w} / \mathrm{w})\end{array}$ & $\begin{array}{c}\mathrm{PO}_{4}^{3-} \\
(\% \mathrm{w} / \mathrm{w})\end{array}$ \\
\hline Rektor and Vatai [44] & Normal whey & 0.46 & & & & & & \\
\hline \multirow[t]{2}{*}{ Blaschek et al. [4] } & Sweet whey & & & & & & 0.20 & \\
\hline & Salty whey & & & & & & 0.50 & \\
\hline \multirow[t]{2}{*}{ Metzger et al. [36] } & Normal whey & & & & $0.05-0.08$ & & & \\
\hline & Stretchwater & & & & $0.01-0.02$ & & & \\
\hline Fernandez and Kosikowski [12] & Normal whey & $0.57-0.68$ & & & & & & \\
\hline \multirow[t]{2}{*}{ Ardisson-Korat and Rizvi [1] } & Normal whey & & & & $0.11-0.12$ & & $0.45-0.68$ & \\
\hline & Stretchwater & & & & $0.01-0.03$ & & $4.62-5.18$ & \\
\hline \multirow[t]{2}{*}{ Hill et al. [20] } & Normal whey & & 0.06 & 0.14 & 0.03 & 0.01 & & 0.04 \\
\hline & Concentrated whey & & $0.11-0.21$ & $0.30-0.50$ & $0.07-0.14$ & $0.01-0.03$ & & $0.08-0.17$ \\
\hline Teixeira and Fonseca [53] & Normal whey & 0.47 & & & & & 0.18 & \\
\hline
\end{tabular}


Table IV. Gross composition of several cheese wheys as found in the literature.

\begin{tabular}{|c|c|c|c|c|c|c|c|c|}
\hline References & Type of whey & $\begin{array}{c}\text { Dry matter } \\
(\% \mathrm{w} / \mathrm{w})\end{array}$ & $\begin{array}{c}\text { Fat } \\
(\% \mathrm{w} / \mathrm{w})\end{array}$ & $\begin{array}{c}\mathrm{TN} \\
(\% \mathrm{w} / \mathrm{w})\end{array}$ & $\begin{array}{l}\text { Proteins } \\
(\% \mathrm{w} / \mathrm{w})\end{array}$ & $\begin{array}{l}\text { Lactose } \\
(\% \mathrm{w} / \mathrm{w})\end{array}$ & $\begin{array}{c}\text { Ash } \\
(\% \mathrm{w} / \mathrm{w})\end{array}$ & $\mathrm{pH}$ \\
\hline Doose (1963) cited by Imbert-Pondaven [21] & $\begin{array}{l}\text { Rennet } \\
\text { Acid }\end{array}$ & $\begin{array}{l}6.00-7.00 \\
5.00-6.00\end{array}$ & $\begin{array}{c}0.10 \\
\text { traces }\end{array}$ & & $\begin{array}{l}0.80-1.00 \\
0.80-1.00\end{array}$ & $\begin{array}{l}4.50-4.80 \\
3.80-4.20\end{array}$ & $\begin{array}{l}0.50-0.70 \\
0.70-0.80\end{array}$ & \\
\hline Blanc (1969) cited by Imbert-Pondaven [21] & $\begin{array}{l}\text { Emmental } \\
\text { Gruyère }\end{array}$ & $\begin{array}{l}6.41-6.60 \\
6.85-6.96\end{array}$ & $\begin{array}{l}0.35-0.56 \\
0.41-0.59\end{array}$ & & $\begin{array}{l}0.65-0.73 \\
0.67-0.73\end{array}$ & $\begin{array}{l}4.59-4.79 \\
4.82-5.05\end{array}$ & $\begin{array}{l}0.48-0.59 \\
0.51-0.56\end{array}$ & \\
\hline Février (1972) cited by Imbert-Pondaven [21] & $\begin{array}{l}\text { Emmental } \\
\text { Fresh cheese }\end{array}$ & $\begin{array}{l}7.00-7.30 \\
6.40-6.50\end{array}$ & $\begin{array}{l}0.50-0.60 \\
0.05-0.09\end{array}$ & & $\begin{array}{l}0.86-0.93 \\
0.60-0.79\end{array}$ & $\begin{array}{l}5.07-5.31 \\
4.34-4.47\end{array}$ & $\begin{array}{l}0.52-0.53 \\
0.73-0.76\end{array}$ & \\
\hline Hargrove et al. [19] & $\begin{array}{l}\text { Cottage } \\
\text { Cheddar }\end{array}$ & $\begin{array}{l}6.42 \\
6.70\end{array}$ & $\begin{array}{l}0.05 \\
0.25\end{array}$ & $\begin{array}{l}0.76 \\
0.83\end{array}$ & $\begin{array}{l}0.53 \\
0.60\end{array}$ & $\begin{array}{l}4.40 \\
5.00\end{array}$ & $\begin{array}{l}0.60 \\
0.52\end{array}$ & $\begin{array}{l}4.70 \\
6.10\end{array}$ \\
\hline Imbert-Pondaven [21] & $\begin{array}{l}\text { Acid } \\
\text { Sweet }\end{array}$ & $\begin{array}{l}6.85 \\
6.61\end{array}$ & & & & $\begin{array}{l}3.99 \\
5.08\end{array}$ & & $\begin{array}{l}4.61 \\
6.55\end{array}$ \\
\hline Kosikowski [31] & $\begin{array}{l}\text { Sweet } \\
\text { Acid }\end{array}$ & $\begin{array}{l}6.35 \\
6.50\end{array}$ & $\begin{array}{l}0.50 \\
0.04\end{array}$ & & $\begin{array}{l}0.80 \\
0.75\end{array}$ & $\begin{array}{l}4.85 \\
4.90\end{array}$ & $\begin{array}{l}0.50 \\
0.80\end{array}$ & \\
\hline Hill et al. [20] & $\begin{array}{l}\text { Cheddar } \\
\text { Cottage }\end{array}$ & $\begin{array}{l}5.90 \\
5.60\end{array}$ & & $\begin{array}{l}0.83 \\
0.62\end{array}$ & & & & $\begin{array}{l}6.13 \\
4.61\end{array}$ \\
\hline Sienkiewicz (1990) cited by Schuck et al. [50] & $\begin{array}{l}\text { Cheddar } \\
\text { Fresh cheese }\end{array}$ & $\begin{array}{l}6.70 \\
6.42\end{array}$ & & $\begin{array}{l}0.83 \\
0.76\end{array}$ & $\begin{array}{l}0.61 \\
0.54\end{array}$ & $\begin{array}{l}5.00 \\
4.40\end{array}$ & $\begin{array}{l}0.52 \\
0.60\end{array}$ & $\begin{array}{l}6.10 \\
4.70\end{array}$ \\
\hline Jeantet et al. [22] & Acid & 6.21 & & 0.71 & & 4.74 & 0.74 & 4.44 \\
\hline
\end{tabular}


Table IV. Continued.

\begin{tabular}{|c|c|c|c|c|c|c|c|c|}
\hline References & Type of whey & $\begin{array}{c}\text { Dry matter } \\
(\% \mathrm{w} / \mathrm{w})\end{array}$ & $\begin{array}{c}\text { Fat } \\
(\% \mathrm{w} / \mathrm{w})\end{array}$ & $\begin{array}{c}\mathrm{TN} \\
(\% \mathrm{w} / \mathrm{w})\end{array}$ & $\begin{array}{l}\text { Proteins } \\
(\% \mathrm{w} / \mathrm{w})\end{array}$ & $\begin{array}{l}\text { Lactose } \\
(\% \mathrm{w} / \mathrm{w})\end{array}$ & $\begin{array}{c}\text { Ash } \\
(\% \mathrm{w} / \mathrm{w})\end{array}$ & $\mathrm{pH}$ \\
\hline \multirow[t]{4}{*}{ De Wit [10] } & Casein & 6.50 & 0.03 & & 0.60 & 4.70 & 0.79 & 4.70 \\
\hline & Acid & 6.50 & 0.03 & & 0.60 & 4.00 & 0.79 & 4.50 \\
\hline & Gouda & 6.50 & 0.05 & & 0.62 & 4.70 & 0.53 & 6.40 \\
\hline & Camembert & 6.50 & 0.05 & & 0.62 & 4.50 & 0.56 & 6.00 \\
\hline \multirow[t]{2}{*}{ Jelen [23] } & Sweet & $6.30-7.00$ & & & $0.60-1.00$ & $4.60-5.20$ & & \\
\hline & Acid & $6.30-7.00$ & & & $0.60-0.80$ & $4.40-4.60$ & & \\
\hline \multirow[t]{2}{*}{ Johansen et al. [25] } & Cheddar-type & 6.13 & 0.35 & & 0.72 & 5.19 & 0.50 & \\
\hline & Dutch-type & 6.38 & 0.15 & & 0.76 & 4.54 & 0.49 & \\
\hline \multirow[t]{4}{*}{ Blaschek et al. [4] } & Cheddar-sweet & 6.60 & 0.20 & & 0.80 & & & \\
\hline & Cheddar-salty & 12.40 & 0.60 & & 0.60 & & & \\
\hline & Colby-sweet & 5.80 & 0.50 & & 0.60 & & & \\
\hline & Colby-salty & 9.80 & 0.80 & & 0.70 & & & \\
\hline Teixeira and Fonseca [53] & Minas Padrao & 6.28 & 0.70 & 0.80 & & 4.12 & 0.49 & 6.30 \\
\hline
\end{tabular}

Abbreviation: $\mathrm{TN}$, total nitrogen. 
Table V. Breakdown of protein composition of several cheese wheys as found in the literature.

\begin{tabular}{|c|c|c|c|c|c|c|c|}
\hline References & Type of whey & $\begin{array}{l}\text { Proteins } \\
(\% \mathrm{w} / \mathrm{w})\end{array}$ & $\begin{array}{c}\text { ALA } \\
(\% \mathrm{WP})\end{array}$ & $\begin{array}{c}\text { BLG } \\
(\% \mathrm{WP})\end{array}$ & $\begin{array}{c}\mathrm{IgG} \\
(\% \mathrm{WP})\end{array}$ & $\begin{array}{c}\text { BSA } \\
(\% \mathrm{WP})\end{array}$ & $\begin{array}{c}\mathrm{LF} \\
(\% \mathrm{WP}) \\
\end{array}$ \\
\hline Doose (1963) cited by Imbert-Pondaven [21] & $\begin{array}{l}\text { Rennet } \\
\text { Acid }\end{array}$ & $\begin{array}{l}0.80-1.00 \\
0.80-1.00\end{array}$ & & & & & \\
\hline Blanc (1969) cited by Imbert-Pondaven [21] & $\begin{array}{l}\text { Emmental } \\
\text { Gruyère }\end{array}$ & $\begin{array}{l}0.65-0.73 \\
0.67-0.73\end{array}$ & & & & & \\
\hline Février (1972) cited by Imbert-Pondaven [21] & $\begin{array}{l}\text { Emmental } \\
\text { Fresh cheese }\end{array}$ & $\begin{array}{l}0.86-0.93 \\
0.60-0.79\end{array}$ & & & & & \\
\hline Hargrove et al. [19] & $\begin{array}{l}\text { Cottage } \\
\text { Cheddar }\end{array}$ & $\begin{array}{l}0.53 \\
0.60\end{array}$ & & & & & \\
\hline Kosikowski [31] & $\begin{array}{l}\text { Sweet } \\
\text { Acid }\end{array}$ & $\begin{array}{l}0.80 \\
0.75\end{array}$ & & & & & \\
\hline De Wit $[10]$ & $\begin{array}{l}\text { Casein } \\
\text { Acid } \\
\text { Gouda } \\
\text { Camembert }\end{array}$ & $\begin{array}{l}0.60 \\
0.60 \\
0.62 \\
0.62\end{array}$ & & & & & \\
\hline Jelen [23] & $\begin{array}{l}\text { Sweet } \\
\text { Acid }\end{array}$ & $\begin{array}{l}0.60-1.00 \\
0.60-0.80\end{array}$ & & & & & \\
\hline Johansen et al. [25] & $\begin{array}{l}\text { Cheddar-type } \\
\text { Dutch-type }\end{array}$ & $\begin{array}{l}0.72 \\
0.76\end{array}$ & & & & & \\
\hline Blaschek et al. [4] & $\begin{array}{l}\text { Cheddar-sweet } \\
\text { Cheddar-salty } \\
\text { Colby-sweet } \\
\text { Colby-salty }\end{array}$ & $\begin{array}{l}0.80 \\
0.60 \\
0.60 \\
0.70\end{array}$ & $\begin{array}{l}24.60 \\
20.00 \\
24.10 \\
21.40\end{array}$ & $\begin{array}{l}57.90 \\
50.40 \\
60.40 \\
53.30\end{array}$ & $\begin{array}{l}4.50 \\
3.00 \\
3.60 \\
2.70\end{array}$ & $\begin{array}{l}2.90 \\
1.70 \\
2.40 \\
2.00\end{array}$ & $\begin{array}{c}1.00 \\
15.00 \\
2.20 \\
14.50\end{array}$ \\
\hline
\end{tabular}

Abbreviations: ALA, $\alpha$-lactalbumin; BLG, $\beta$-lactoglobulin; IgG, immunoglobulin- $\gamma$; BSA, bovine serum albumin; LF, lactoferrin. 
are a shorter processing time, a cheaper production system and a saving in cooling water, due to the fact that the pats are smaller and quicker to cool.

The diversity of Mozzarella cheese manufacturing processes means that it is difficult to consider Mozzarella cheese whey as a single product. We shall therefore use the term Mozzarella cheese wheys in this review, their composition being closely related to the manufacturing process they originate from.

\section{MOZZARELLA CHEESE WHEYS AND STRETCHWATERS}

\subsection{Composition of Mozzarella cheese wheys}

Characterization of the wheys produced by the different Mozzarella cheese manufacturing methods is essential for the study of concentration, crystallization and drying of these matrices. It is therefore interesting to look initially at the literature concerning this whey category.

Tables I-III show the composition of the Mozzarella cheese wheys and stretchwaters found in the literature. The different types of whey and stretchwater are specified, but when no information concerning whey origin was available, it has been considered as "normal whey".

There are in fact very few studies available on the composition of whey and most of the information given here is from studies on Mozzarella manufacture, thus focusing mainly on the mass balance of cheese production and cheese yield. The compositions given are therefore fairly incomplete.

It can be seen that there is variability in the composition of Mozzarella cheese wheys, depending on the process used. Thus, whey originating from $0.1 \mu \mathrm{m}$ microfiltration according to the process described by Ardisson-Korat and Rizvi [1] is about twice as concentrated as others, whether in terms of fat, proteins or total solids. However, the amount of whey produced by this process is scant compared to the amounts produced by techniques without filtration.

However, even in the latter wheys, there are differences in fat $(0.06-0.79 \%)$, proteins $(0.7-1.6 \%)$, whey proteins $(0.01-8.9 \%$ of total whey proteins for lactoferrin) and lactose; the small amount of lactose found by Rektor and Vatai [44] indicates the possible presence of residual lactose hydrolysis or fermentation products. Fernandez and Kosikowski [12] did not find such low lactose content in whey originating from the control test when reporting the lactose content of the wheys produced during their tests, whether control or retentate-originating.

Rektor and Vatai [44] do not provide details about the origin of their whey, which had a high fat concentration and low dry matter. It is therefore difficult to rely on the composition of this whey.

However, there is evidence on an industrial scale that Mozzarella cheese wheys contain galactose (personal communication).

Tables IV-VI show the gross composition and breakdown of proteins and minerals of several wheys reported in the literature.

Making a comparison with the values presented in Tables I-III, there is no significant difference in composition between a normal Mozzarella cheese whey and a typical sweet whey such as gouda cheese whey.

One possible explanation for this apparent paradox is the lack of information regarding Mozzarella cheese wheys. For example, the amounts of organic acids and sugars (except for lactose in three references) were not provided. No study shows exhaustive mineral composition, the composition given by Hill et al. [20] being the most complete.

A second, though less likely, explanation may be that the difficulties occurring during processing of Mozzarella cheese whey are explained by the presence of compounds that are not measured, such as ropy exopolysaccharides or small molecules such as ammonia. 
Table VI. Breakdown of the mineral composition of several cheese wheys as found in the literature.

\begin{tabular}{|c|c|c|c|c|c|c|c|c|}
\hline References & Type of whey & $\begin{array}{c}\text { Ash } \\
(\% \mathrm{w} / \mathrm{w})\end{array}$ & $\begin{array}{c}\mathrm{Na}^{+} \\
(\% \mathrm{w} / \mathrm{w})\end{array}$ & $\begin{array}{c}\mathrm{K}^{+} \\
(\% \mathrm{w} / \mathrm{w}) \\
\end{array}$ & $\begin{array}{l}\mathrm{Ca}^{2+} \\
(\% \mathrm{w} / \mathrm{w})\end{array}$ & $\begin{array}{l}\mathrm{Mg}^{2+} \\
(\% \mathrm{w} / \mathrm{w})\end{array}$ & $\begin{array}{c}\mathrm{Cl}^{-} \\
(\% \mathrm{w} / \mathrm{w}) \\
\end{array}$ & $\begin{array}{r}\mathrm{PO}_{4}{ }^{3-} \\
(\% \mathrm{w} / \mathrm{w})\end{array}$ \\
\hline $\begin{array}{l}\text { Doose (1963) cited by Imbert-Pondaven } \\
\text { [21] }\end{array}$ & $\begin{array}{l}\text { Rennet } \\
\text { Acid }\end{array}$ & $\begin{array}{l}0.50-0.70 \\
0.70-0.80\end{array}$ & & & & & & \\
\hline $\begin{array}{l}\text { Blanc (1969) cited by Imbert-Pondaven } \\
\text { [21] }\end{array}$ & $\begin{array}{l}\text { Emmental } \\
\text { Gruyère }\end{array}$ & $\begin{array}{l}0.48-0.59 \\
0.51-0.56\end{array}$ & & & $\begin{array}{l}0.03-0.04 \\
0.03-0.04\end{array}$ & & & \\
\hline $\begin{array}{l}\text { Février (1972) cited by Imbert-Pondaven } \\
\text { [21] }\end{array}$ & $\begin{array}{l}\text { Emmental } \\
\text { Fresh cheese }\end{array}$ & $\begin{array}{l}0.52-0.53 \\
0.73-0.76\end{array}$ & & & $\begin{array}{c}0.04 \\
0.13-0.14\end{array}$ & & & \\
\hline Hargrove et al. [19] & $\begin{array}{l}\text { Cottage } \\
\text { Cheddar }\end{array}$ & $\begin{array}{l}0.60 \\
0.52\end{array}$ & & & & & & \\
\hline Wong et al. [56] & $\begin{array}{l}\text { Acid } \\
\text { Sweet }\end{array}$ & & $\begin{array}{l}0.04 \\
0.05\end{array}$ & $\begin{array}{l}0.15 \\
0.12\end{array}$ & $\begin{array}{l}0.09 \\
0.04\end{array}$ & $\begin{array}{l}0.01 \\
0.01\end{array}$ & & $\begin{array}{l}0.06 \\
0.04\end{array}$ \\
\hline Kosikowski [31] & $\begin{array}{l}\text { Sweet } \\
\text { Acid }\end{array}$ & $\begin{array}{l}0.50 \\
0.80\end{array}$ & & & & & & \\
\hline Hill et al. [20] & $\begin{array}{l}\text { Cheddar } \\
\text { Cottage }\end{array}$ & & $\begin{array}{l}0.06 \\
0.06\end{array}$ & $\begin{array}{l}0.15 \\
0.13\end{array}$ & $\begin{array}{l}0.04 \\
0.09\end{array}$ & $\begin{array}{l}0.01 \\
0.01\end{array}$ & & $\begin{array}{l}0.04 \\
0.06\end{array}$ \\
\hline $\begin{array}{l}\text { Sienkiewicz (1990) cited by Schuck et al. } \\
\text { [50] }\end{array}$ & $\begin{array}{l}\text { Cheddar } \\
\text { Fresh cheese }\end{array}$ & $\begin{array}{l}0.52 \\
0.60\end{array}$ & & & & & & \\
\hline
\end{tabular}


Table VI. Continued.

\begin{tabular}{|c|c|c|c|c|c|c|c|c|}
\hline References & Type of whey & $\begin{array}{c}\text { Ash } \\
(\% \mathrm{w} / \mathrm{w})\end{array}$ & $\begin{array}{c}\mathrm{Na}^{+} \\
(\% \mathrm{w} / \mathrm{w})\end{array}$ & $\begin{array}{c}\mathrm{K}^{+} \\
(\% \mathrm{w} / \mathrm{w})\end{array}$ & $\begin{array}{c}\mathrm{Ca}^{2+} \\
(\% \mathrm{w} / \mathrm{w})\end{array}$ & $\begin{array}{c}\mathrm{Mg}^{2+} \\
(\% \mathrm{w} / \mathrm{w})\end{array}$ & $\begin{array}{c}\mathrm{Cl}^{-} \\
(\% \mathrm{w} / \mathrm{w})\end{array}$ & $\begin{array}{c}\mathrm{PO}_{4}{ }^{3-} \\
(\% \mathrm{w} / \mathrm{w})\end{array}$ \\
\hline Jeantet et al. [22] & Acid & 0.74 & 0.04 & 0.15 & 0.12 & 0.01 & 0.26 & 0.07 \\
\hline De Wit [10] & $\begin{array}{l}\text { Casein } \\
\text { Acid } \\
\text { Gouda } \\
\text { Camembert }\end{array}$ & $\begin{array}{l}0.79 \\
0.79 \\
0.53 \\
0.56\end{array}$ & & & $\begin{array}{l}0.16 \\
0.16 \\
0.06 \\
0.06\end{array}$ & & & $\begin{array}{l}0.10 \\
0.10 \\
0.07 \\
0.07\end{array}$ \\
\hline Johansen et al. [25] & $\begin{array}{l}\text { Cheddar-type } \\
\text { Dutch-type }\end{array}$ & $\begin{array}{l}0.50 \\
0.49\end{array}$ & & & & & & \\
\hline Cataldi et al. [6] & $\begin{array}{l}\text { Soft cheese } \\
\text { Hard cheese }\end{array}$ & & $\begin{array}{l}0.05 \\
0.04\end{array}$ & $\begin{array}{l}0.16 \\
0.17\end{array}$ & $\begin{array}{l}0.06 \\
0.02\end{array}$ & $\begin{array}{l}0.01 \\
0.01\end{array}$ & $\begin{array}{l}0.12 \\
0.11\end{array}$ & $\begin{array}{l}0.12 \\
0.08\end{array}$ \\
\hline Blaschek et al. [4] & $\begin{array}{l}\text { Cheddar-sweet } \\
\text { Cheddar-salty } \\
\text { Colby-sweet } \\
\text { Colby-salty }\end{array}$ & & & & & & $\begin{array}{l}0.20 \\
6.90 \\
0.10 \\
4.00\end{array}$ & \\
\hline Teixeira and Fonseca [53] & Minas Padrao & 0.49 & & & & & 0.20 & \\
\hline
\end{tabular}


The heterogeneity of the composition of Mozzarella cheese wheys found in the literature, and the lack of information concerning their full composition, indicate that their composition should be investigated further.

\subsection{Impact of composition of Mozzarella cheese wheys on water elimination stages}

Evaporation, lactose crystallization and spray drying of whey have one common goal: to decrease the water activity by removing water from the product. Water elimination is especially difficult in complex products such as whey, due to the presence of hygroscopic compounds. These compounds can hinder each of the stages of water elimination.

\subsubsection{Impact of composition on evaporation}

Being preliminary to both subsequent operations, evaporation is a critical operation. Although there is no information concerning these issues, the desired dry matter is not achieved on an industrial scale in the case of Mozzarella wheys (personal communication, unpublished data), and this may be related to the specific composition of Mozzarella wheys.

\subsubsection{Impact of composition on lactose crystallization}

The lactose crystallization operation is strongly linked with the other two processing stages. In fact, adequate supersaturation can only be achieved if the preceding concentration step is satisfactorily achieved. Similarly, the subsequent spray-drying step is dependent on obtaining a certain degree of crystallization. Lactose crystallization is therefore a central processing step in water elimination.

The composition of whey is a parameter that should be taken into account seriously when optimizing this processing stage, as many compounds are likely to modify the way in which lactose is crystallized, either by directly affecting the lactose crystallization stage or by modifying the supersaturated solution characteristics.

Many studies have shown how composition can directly affect the crystallization stage. Sugars can influence lactose crystallization. For example, galactose has been shown to be a habit modifier of the crystal of $\alpha$-lactose monohydrate [14], in other words, a strong inhibitor of the growth of some faces. Proteins can also modify the way in which lactose is crystallized. Mimouni et al. [39] showed that whey proteins have a tendency to lower the size of crystals of $\alpha$-lactose monohydrate. They hypothesized that, being hydrophilic, whey proteins retain crystallization water and create local supersaturation spots that are more prone to nucleation than to crystal growth. Mimouni [37] studied the effects of whey proteins by modelling and showed that they accelerate the first phases of crystallization, which are kinetically dependent on nucleation and crystal growth, their reducing effect on average crystal size showing that they accelerate the nucleation step but slow crystal growth, the exact mechanisms being unknown. The effects of the minerals in whey on lactose crystallization have been mainly studied in model solutions. The study of Guu and Zall [17], based on an experimental design testing associations of minerals found in wheys, showed that crystal growth was related to the combined effects of calcium, phosphate and potassium and an interaction factor between phosphate and potassium. As the minerals favouring crystal growth are calcium and phosphate, the authors hypothesized that the formation of phosphocalcic micelles could improve crystallization by forming nuclei. However, their results also showed that when considered separately, the potassium, calcium and sodium ions could inhibit lactose crystallization. Smart and Smith [51] also showed the accelerating effect of certain phosphate salts 
on crystal growth. However, the phosphocalcic salts had no effect and resulted in incorporation of these salts into the crystal lattice. Jelen and Coulter [24] studied the effects of different mineral salts on the crystallization rate and showed varying effects, depending on mineral concentration, the accelerating effect of calcium chloride reaching a maximum for a concentration of $10 \%$ on a dry weight basis. Similarly, potassium chloride, which has an activating effect at lower concentrations, has an inhibitory effect above $5 \%$ dry weight. The effects of minerals on lactose crystallization are thus complex, several interactions being possible; moreover, studies on the effects of minerals have focused mainly on the effects of minerals on crystal growth, but the mineral composition can also influence the mutarotation kinetics [18].

Composition can also influence lactose crystallization by modifying the properties of the supersaturated solution. In a study of lactose crystallization in concentrated wheys, Modler and Lefkovitch [40] concluded that an excess of denatured whey proteins increases the viscosity of the aqueous phase and decreases the size of the crystals observed. It has recently been reported that the formation of calcium lactate crystals in acid wheys during the lactose crystallization stage could lead to thickening of whey, resulting in various problems such as pump transfer of whey [38].

\subsubsection{Impact of composition on spray drying}

Spray drying is particularly difficult in the case of Mozzarella cheese wheys. In fact, Mozzarella cheese wheys are never dried alone, but are always mixed with other wheys. Spray-drying ability of a product can be strongly influenced by many factors, particularly its glass transition temperature $\left(T_{\mathrm{g}}\right)$. This is especially the case for whey that may contain various compounds with low $T_{\mathrm{g}}$.
Table VII. Glass transition temperature $\left(T_{\mathrm{g}}\right)$ of several dry dairy ingredients. (Adapted from [48].)

\begin{tabular}{lc}
\hline Ingredients & $T_{\mathrm{g}}\left({ }^{\circ} \mathrm{C}\right)$ \\
\hline Glucose & 36 \\
Galactose & 30 \\
Lactulose & -2 \\
Lactose & 97 \\
Skimmed milk & 92 \\
Milk & 92 \\
Hydrolysed milk & 49 \\
Casein & 144 \\
Sodium caseinate & 130 \\
\hline
\end{tabular}

Whey glass transition is affected by the different compounds involved in glass transition, i.e. mainly sugars and proteins, and salts of organic acids such as lactate and citrate, these compounds being present in Mozzarella wheys (unpublished data). Table VII shows the glass transition temperature of some compounds that are present in dairy products. Among sugars, it is of interest to note that glucose and galactose have lower glass transition temperatures than lactose. Schuck et al. [49] developed a stickiness and caking sensitivity index that, on the basis of the characteristics of a powder (glass transition and change in thermal capacity) and the process, makes it possible to assess the risk of stickiness and/or caking.

Apart from their depressing effect on $T_{\mathrm{g}}$, galactose and glucose may have a retaining effect on solvent water. In fact, there is evidence that hydrolysed lactose dairy products are difficult to dry, due to the greater hygroscopicity of glucose and galactose [45].

Minerals can also have a negative impact on water elimination. For example, acid wheys, which are particularly difficult to dry, have a high acid and mineral content. The quality of the powders obtained is greatly improved by demineralizing them, either by electrodialysis, ion exchange and/or nanofiltration, as shown by Jeantet et al. [22] for nanofiltration. 
An understanding of the overall composition of whey, including minor compounds, is therefore important to explain various problems affecting whey transformation processes, especially water elimination.

\section{CONCLUSION}

There are various manufacturing processes for Mozzarella cheese related to the demands for several cheese properties, ranging from, on the one hand those of the cheese maker, to those of pizza manufacturers and consumers on the other. The differences include the use of a starter and/or acid for the acidification step, the solving of functionality defects due to the reduction in fat content and various parameters of the process (salting and temperatures). These differences between the processes lead to heterogeneity of whey composition. The information available in the literature originates from studies of cheese making, cheese yield and functional properties, the interest in whey composition being solely for the control of losses and involving only gross measurements (dry matter, total proteins and fat content). Despite the fact that these results show diversity, they do not provide a sufficient background regarding the overall composition of such wheys, or the amounts of some minor compounds which might explain the difficulties occurring in concentration, lactose crystallization and spray drying. A good understanding of the mechanisms involved in the concentration, lactose crystallization and spray-drying defects of these wheys requires an improved knowledge of their composition. The accurate characterization of the composition of Mozzarella cheese wheys is therefore a prerequisite to further research into the effects of certain compounds on the concentration, lactose crystallization and spray-drying stages of Mozzarella cheese wheys. It can be hypothesized that the problems occurring during these stages have different causes depending on the technology producing the whey or permeate, whether it is cheese technology or the different fractionation techniques that can deplete or enrich the permeate in different compounds. The physicochemical characterization and the subsequent study of the effects of different compounds to identify those most involved in the inhibition of the concentration, crystallization and spray-drying stages should therefore be combined with a typology of the different technological origins of the wheys analysed, in order to pinpoint the processing steps during which an imbalance can occur.

Greater understanding of the factors leading to the difficulties in the different stages of the drying of Mozzarella cheese wheys will thus provide technological solutions to remove or transform the compounds involved.

Acknowledgements: We are grateful to GEA Process Engineering for its collaboration in this project. GEA Process Engineering France, 4 rue J.P. Timbaud - B.P. 80, Montignyle-Bretonneux, 78185 Saint-Quentin-en-Yvelines, France. Web site: www.gea-pe.fr.

\section{REFERENCES}

[1] Ardisson-Korat A.V., Rizvi S.S.H., Vatless manufacturing of low-moisture part-skim Mozzarella cheese from highly concentrated skim milk microfiltration retentate, J. Dairy Sci. 87 (2004) 3601-3613.

[2] Barbano D.M., Yun J.J., Kindstedt P.S., Mozzarella cheese making by a stirred curd, no brine procedure, J. Dairy Sci. 77 (1994) 2687-2694.

[3] Baskaran D., Sivakumar S., Galactose concentration in pizza cheese prepared by three different culture techniques, Int. J. Dairy Technol. 56 (2003) 229-232.

[4] Blaschek K.M., Wendorff W.L., Rankin S.A., Survey of salty and sweet whey composition from various cheese plants in Wisconsin, J. Dairy Sci. 90 (2007) 2029-2034.

[5] Breene W.M., Price W.V., Ernstrom C.A., Manufacture of pizza cheese without starter, J. Dairy Sci. 47 (1964) 1173-1180. 
[6] Cataldi T.R.I., Angelotti M., D’Erchia L., Altieri G., Di Renzo G.C., Ion-exchange chromatographic analysis of soluble cations, anions and sugars in milk whey, Eur. Food Res. Technol. 216 (2003) 75-82.

[7] Chen C.M., Johnson M.E., Pasta filatasimulative cheese product and method of making, US Pat. No. 5942263, 1999.

[8] CNIEL, L'économie laitière en chiffres, Éditions 1998 à 2007, Centre National Interprofessionnel de l'Économie Laitière, Paris, France.

[9] Dairy Management Inc., Innovations in Dairy, December 1998, http://www.innovatewithdairy.com/NR/rdonlyres/16393 F85-C6E94449-B718-8E0352F133DA/0/G1 InnovationsDec98.pdf.

[10] De Wit J.N., Lecturer's Handbook on Whey and Whey Products, 1 st edn., European Whey Products Association, Brussels, Belgium, 2001.

[11] Doultani S., Turhan K.N., Etzel M.R., Fractionation of proteins from whey using cation exchange chromatography, Process Biochem. 39 (2004) 1737-1743.

[12] Fernandez A., Kosikowski F.V., Low moisture Mozzarella cheese from whole milk retentates of ultrafiltration, J. Dairy Sci. 69 (1986) 2011-2017.

[13] Ferrari E., Gamberi M., Manzini R., Pareschi A., Persona A., Regattieri A., Redesign of the Mozzarella cheese production process through development of a micro-forming and stretching extruder system, J. Food Eng. 59 (2003) 13-23.

[14] Garnier S., Petit S., Coquerel G., Influence of supersaturation and structurally related additives on the crystal growth of $\alpha$-lactose monohydrate, J. Crystal Growth 234 (2002) 207-219.

[15] Guinee T.P., Feeney E.P., Auty M.A.E., Fox P.F., Effect of $\mathrm{pH}$ and calcium concentration on some textural and functional properties of Mozzarella cheese, J. Dairy Sci. 85 (2002) 1655-1669.

[16] Guinee T.P., Mulholland E.O., Mullins C., Corcoran M.O., Effect of salting method on the composition, yield and functionality of low moisture Mozzarella cheese, Milchwissenschaft 55 (2000) 135-138.

[17] Guu M.Y.K., Zall R.R., Lactose crystallization: effect of minerals and seeding, Process Biochem. 26 (1991) 167-172.
[18] Haase G., Nickerson T.A., Kinetic reactions of alpha and beta lactose. I. Mutarotation, J. Dairy Sci. 49 (1966) 127-132.

[19] Hargrove R.E., McDonough F.E., Lacroix D.E., Alford J.A., Production and properties of deproteinized whey powders, J. Dairy Sci. 59 (1976) 25-33.

[20] Hill A.R., Irvine D.M., Bullock D.H., Buffer capacity of cheese wheys, J. Food Sci. 50 (1985) 733-738.

[21] Imbert-Pondaven A., Étude de l'évolution de la composition des lactosérums au cours de leur conservation, Lait 57 (1977) 521-546.

[22] Jeantet R., Schuck P., Famelart M.H., Maubois J.L., Intérêt de la nanofiltration dans la production de poudres de lactosérum démineralisées, Lait 76 (1996) 283-301.

[23] Jelen P., Whey processing: utilization and products, in: Encyclopedia of Dairy Sciences, Elsevier, London, UK, 2002, pp. 2739-2745.

[24] Jelen P., Coulter S.T., Effects of certain salts and other whey substances on the growth of lactose crystals, J. Food Sci. 38 (1973) 1186-1189.

[25] Johansen A.G., Vegarud G.E., Skeie S., Seasonal and regional variation in the composition of whey from Norvegian Cheddartype and Dutch-type cheese, Int. Dairy J. 12 (2002) 621-629.

[26] Keller B., Olson N.F., Richardson T., Mineral retention and rheological properties of Mozzarella cheese made by direct acidification, J. Dairy Sci. 57 (1973) 174-180.

[27] Kindstedt P.S., Effect of manufacturing factors, composition, and proteolysis on the functional characteristics of Mozzarella cheese, Crit. Rev. Food Sci. Nut. 33 (1993) 167-187.

[28] Kindstedt P.S., Mozzarella cheese: 40 years of scientific advancement, Int. J. Dairy Technol. 57 (2004) 85-90.

[29] Kindstedt P.S., Rowney M., Roupas P., Technology, biochemistry and functionality of pasta filata/pizza cheese, in: Law B.A. (Ed.), Technology of Cheesemaking, Sheffield Academic Press, Sheffield, UK, 1999, pp. 193-221.

[30] Kosikowski F.V., The manufacture of Mozzarella and related cheese by ultrafiltration, Cult. Dairy Prod. J. (November 1975) 15-16.

[31] Kosikowski F.V., Whey utilization and whey products, J. Dairy Sci. 62 (1979) 1149-1160. 
[32] McMahon D.J., Paulson B., Oberg C.J., Influence of calcium, $\mathrm{pH}$, and moisture on protein matrix structure and functionality in direct-acidified nonfat Mozzarella cheese, J. Dairy Sci. 88 (2005) 3754-3763.

[33] Mann E., Mozzarella cheese, Dairy Ind. Int. (December 1999) 15-16.

[34] Maubois J.-L., Mocquot G., Vassal L., A method for processing milk and dairy products, Fr. Pat. No. 2052121, 1969.

[35] MDC Datum, Dairy Market Update (7 July 2006), http://www.mdcdatum.org.uk/.

[36] Metzger L.E., Barbano D.M., Rudan M.A., Kindstedt P.S., Effect of milk preacidification on low fat Mozzarella cheese. I. Composition and yield, J. Dairy Sci. 83 (2000) 648-658.

[37] Mimouni A., Cristallisation du lactose et épaississement dans les lactosérums concentrés, Ph.D. Thesis, ENSAR, France, 2007.

[38] Mimouni A., Bouhallab S., Famelart M.H., Naegele D., Schuck P., The formation of calcium lactate crystals is responsible for concentrated acid whey thickening, J. Dairy Sci. 90 (2007) 57-65.

[39] Mimouni A., Schuck P., Bouhallab S., Kinetics of lactose crystallization and crystal size as monitored by refractometry and laser light scattering: effect of proteins, Lait 85 (2005) 253-260.

[40] Modler H.W., Lefkovitch L.P., Influence of $\mathrm{pH}$, casein, and whey protein denaturation on the composition, crystal size, and yield of lactose from condensed whey, J. Dairy Sci. 69 (1986) 684-697.

[41] Perry D.B., McMahon D.J., Oberg C.J., Effect of exopolysaccharide-producing cultures on moisture retention in low-fat Mozzarella cheese, J. Dairy Sci. 80 (1997) 799-805.

[42] Petersen B.L., Dave R.I., McMahon D.J., Oberg C.J., Broadbent J.R., Influence of capsular and ropy exopolysaccharide-producing Streptococcus thermophilus on Mozzarella cheese and cheese whey, J. Dairy Sci. 83 (2000) 1952-1956.

[43] Punidadas P., Feirtag J., Tung M.A., Incorporating whey proteins into Mozzarella cheese, Int. J. Dairy Technol. 52 (1999) $51-55$.
[44] Rektor A., Vatai G., Membrane filtration of Mozzarella whey, Desalination 162 (2004) 279-286.

[45] Rheinländer P.M., Drying of hydrolyzed whey, Nordeuropaeisk Mejeri-Tiddskr. 48 (1982) 121-126.

[46] Rudan M.A., Barbano D.M., Yun J.J., Kindstedt P.S., Effect of fat reduction on chemical composition, proteolysis, functionality, and yield of Mozzarella cheese, J. Dairy Sci. 82 (1999) 661-672.

[47] Schafer H.W., Olson N.F., Characteristics of Mozzarella cheese made by direct acidification from ultra-high-temperature processed milk, J. Dairy Sci. 58 (1974) 494-501.

[48] Schuck P., L'eau, in: Science des aliments, Tome 1: Stabilisation biologique et physicochimique, Éditions Tec et Doc, Lavoisier, Paris, 2006, pp. 13-32.

[49] Schuck P., Blanchard E., Dolivet A., Méjean S., Onillon E., Jeantet R., Water activity and glass transition in dairy ingredients, Lait 85 (2005) 295-304.

[50] Schuck P., Bouhallab S., Durupt D., Vareille P., Humbert J.-P., Marin M., Séchage des lactosérums et dérivés : rôle du lactose et de la dynamique de l'eau, Lait 84 (2004) 243-268.

[51] Smart J.B., Smith J.M., Effect of selected compounds on the rate of $\alpha$-lactose monohydrate crystallization, crystal yield and quality, Int. Dairy J. 1 (1991) 41-53.

[52] Smithers G.W., Whey and whey proteinsFrom "gutter-to-gold", Int. Dairy J. 18 (2008) 695-704.

[53] Teixeira L.V., Fonseca L.M., Physical-chemical profile of the whey of Minas-padrão and Mozzarella cheeses produced in some regions of Minas Gerais state, Arq. Bras. Med. Vet. Zootec. 60 (2008) 243-250.

[54] Walsh C.D., Guinee T.P., Harrington D., Mehra R., Murphy J., Fitzgerald R.J., Cheesemaking, compositional and functional characteristics of low-moisture partskim Mozzarella cheese from bovine milks containing $\kappa$-casein $\mathrm{AA}, \mathrm{AB}$ or $\mathrm{BB}$ genetic variants, J. Dairy Res. 65 (1998) 307-315.

[55] Webb B.H., Whittier E.O., The utilization of whey: a review, J. Dairy Sci. 31 (1948) 139-164.

[56] Wong N.P., LaCroix D.E., McDonough F.E., Minerals in whey and whey fractions, J. Dairy Sci. 61 (1978) 1700-1703. 